\title{
Global Engineering Services: Shedding Light on Network Capabilities
}

\begin{abstract}
This paper addresses the operations challenges of effectively managing professional services on a global scale. The specific context for the study is professional engineering services and particularly those that are delivered globally - global engineering services (GES). Estimates suggest that the market for GES was around US\$930 billion in 2012, rising to US\$1.4 trillion by 2020 (ISG, 2013). Yet this influential sector receives scant attention in the operations management literature. The paper draws on six case studies to explore the operations management challenges of delivering GES. In doing so the paper introduces the concept of network capabilities for GES, highlighting the centrality that: (i) network resources - accessing and deploying dispersed resources, (ii) network coordination - coordinating and integrating network activities, and (iii) network learning - collective learning and knowledge management, all play in enabling the successful operational management of GES.
\end{abstract}

Key Words: Global Engineering Services (GES), Network Capabilities, Professional Service Operations Management (PSOM)

\section{Background and Introduction}

Professional services provide a significant research opportunity for the Operations Management $(\mathrm{OM})$ community. They are a major plank in the modern economy and represent a "very different context for developing OM tools and techniques (Lewis and Brown 2012: p2)". However there is a relative dearth of in-depth exploration of the specific operations challenges of professional services (Løwendahl 2005; Heineke and Davis 2007; Goodale et al 2008; Lewis and Brown 2012). That literature on professional service operations management (PSOM) that does exist is largely limited to a few classic types of professional services such as legal services (Lewis and Brown 2012), healthcare services (Heineke 1995) and social services (Harvey 1992). There is an "urgent need to move beyond [these classic types of professional services] in order to compare them with other categories (von Nordenflycht 2010:p171)"; and only by doing so, we will be in a position to possibly tease out effective organisational features for professional services in a particular operations context.

This research focuses on a new domain of professional services - global engineering services (GES). We have chosen to study the operations management challenges of GES because they have both traditionally been under-studied and they epitomise a significant archetypal change that many 
professional service firms are facing. In short, professional service firms are shifting from the traditional organisational model of a professional partnership to a more knowledge-based, technology-enabled, globally-networked organisation (Roth and Menor 2003; Brock et al. 2007; Chase and Apte 2007; Abdelzaher 2012). One could argue that GES firms are at the forefront of this organisational transformation. They are pioneering new forms of network based organisations as a result of the nature of the knowledge they deploy, the degree of jurisdictional control they exercise, and the global client relationships they seek (Malhotra and Morris 2009; Zhang et al. 2014). From a knowledge perspective, GES firms tend to adopt lateral team structures and reciprocal processes since they have a technical or syncretic knowledge base supported by multiple disciplines rather than a normative knowledge base. From a jurisdiction perspective, engineering professions have weaker social closure and looser geographic jurisdictional boundaries; therefore it is relatively easy for GES firms to form a global network structure. From a client perspective, GES require a high degree of face-to-face client interaction in the production process, and thus a high degree of geographic dispersion of assets especially when their clients are geographically dispersed.

In parallel with other professional services firms, it is clear that network organisations play an increasingly important role in GES. Key driving forces include the expansion of large, multinational engineering services firms, increasing geographic dispersion of engineering capabilities (including the human capabilities embedded in the work force), an emerging global race for talent (Lewin et al. 2009) and opportunities made available by the progress of information technology (Apte and Mason 1995; Lannes 2001; NAE 2004; Zhang and Gregory 2011). As a result of their global network structures, GES firms face critical operations challenges in organising and coordinating dispersed engineering activities across geographic and organisational boundaries. The challenges are compounded by the fact that engineering capabilities are often complex, intangible, invisible and embedded in different operational areas (RAEng 2010; Krull et al. 2012; Zhang and Gregory 2013). These difficulties and challenges have been recognised by scholars studying professional services from various theoretical perspectives, e.g. aligning operational capabilities to different types of service operations (Coltman and Devinney 2013), recognising the unique requirement of organisational innovation for services (Droege et al. 2009), understanding the performance implications of managerial decisions in service operations (Heineke 1995), and coping with coordination challenges in complex service operations (Harvey 1992; 2011).

One of the key operations challenges facing network based professional service organisations, including GES firms, is how to build effective network capabilities in a global context. Using existing studies this paper sets out a theoretical foundation that is used to explore the question"how do engineering services firms develop network capabilities for effective value creation in 
global service operations". Through six case analysis covering a range of GES firms we reach the conclusion that critical network capabilities include: (i) network resources - accessing and deploying dispersed resources, (ii) network coordination - coordinating and integrating network activities, and (iii) network learning - collective learning and knowledge management.

\section{Theoretical Foundation}

\section{- Global engineering services (GES)}

We consider global engineering services (GES) as the application of engineering knowledge (including engineering technologies, skills and expertise) possessed by an engineering services firm in effective problem-solving for the benefit of customers in a global context. These services are typically knowledge-intensive, asset-light, and customer/project-focused (Malhotra and Morris 2009; Zhang et al. 2014).

GES are one of the largest professional services industries in the world - ISG (2013) estimated the global spend on engineering services to be around US\$930 billion in 2012, rising to US\$1.4 trillion by 2020. A report from the Centre on Globalisation, Governance and Competitiveness at Duke University (Fernandez-Stark et al. 2010) suggests global revenues from the combined construction and engineering industries were US\$2.7 trillion in 2013. Viewing engineering services in a broader scene - as part of the professional services market - further emphasises their importance to the global economy. The UK provides an apposite example - her professional and business services sectors (excluding financial services) are a global success story. The UK's share of OECD exports is $12 \%$, second only to the US at $17 \%$ in 2011 (HM Government 2013). Engineering, the $2^{\text {nd }}$ largest segment in these sectors, contributed to $1.5 \%$ of UK total GVA and $1.6 \%$ of UK total employment in the same year (ONS 2014).

Within the $\mathrm{K}$ (knowledge intensity), L(low capital intensity), $\mathrm{P}$ (professional workforce) and C(customisation) typology proposed by von Nordenflycht $(2010 ; 2011)$, GES were labelled in Category 1-technology developers (e.g. research labs) and Category 4-classic professional service firms (e.g. architecture). This on the one hand indicates the diversity of GES; and on the other hand highlights the need for collaboration among different types of engineering services for effective value co-creation (Zhang and Gregory 2011). For example, research services and design services in the aforementioned categories 1 and 4 often co-exist in the business portfolio of a large engineering services firm. Nevertheless, the diversity of GES allowed us to examine "how a distinctive group of firms becomes optimally organised as contexts change" - a key opportunity for future research in professional services identified by Zardkoohi et al. (2011: p184). 
From an evolutionary perspective, GES share a common ground with the latest type of services operations- information services, since many engineering services firms "have expanded their service offering by providing information that assists customers with decision making” (Heineke and Davis 2007:p367). Such expansion has resulted in workforces dispersed across geographic, organisational and disciplinary boundaries; and thus driving the evolving organisation structure from the traditional partnership management towards network forms of organisations (Greenwood et al. 2002; Malhotra and Morris 2009: Zhang et al. 2014). GES have to cope with new challenges in organising and coordinating these increasingly dispersed, complex, diverse, dynamic service networks (Heineke and Davis 2007).

\section{- The concept of capabilities}

Organisational capabilities are a key concept in the strategic management literature referring to the ability of a bundle of resources to perform some tasks or activities (Grant 1991; Barney 1999; Winter 2003; Coltman and Devinney 2013). OM scholars have conceptualised capabilities as intended or actual operational strengths contributing to an organisation's competitive performance (Hayes and Wheelwright 1984; Slack and Lewis 2002; Voss 2005). Capabilities leading to sustainable competitive advantage are critical to businesses, will directly contribute to customer value, and are often embedded in different functional areas (Prahalad and Hamel 1990; Javidan 1998; Quinn 1999). In a changing environment, an organisation will need dynamic capabilities to create, integrate and reconfigure resources into new sources of competitive advantage (Teece et al. 1997; Eisenhardt and Martin 2000; Helfat and Peteraf 2003; Anand et al. 2009; Cetindamar et al. 2009). Capability building is not simply a matter of assembling a bundle of resources, because capabilities involve complex patterns of coordination (or routines), cooperation and integration between people and other resources (Mills and Platts 2003; Winter 2003).

\section{- Network capabilities}

As previously discussed, GES firms face critical operations challenges in organising and coordinating dispersed engineering activities across geographic and organisational boundaries. The traditional literature on capabilities has been extended to encompass situations such as this through discussion of network capabilities (Foss 1999; Håkansson et al. 2009). Network organisations are characterised by horizontal patterns of exchange, interdependent flows of resources, and reciprocal lines of communication (Powell 1990; Podolny and Page 1998; Koka et al. 2006). In a network, transactions occur neither through discrete exchanges nor by administrative orders, but through the network of individual members engaged in reciprocal, preferential, and mutually supportive actions. From this point of view, network capabilities have been widely considered as the collective ability 
or learning of network members to achieve some strategic objectives through accessing and deploying dispersed resources (Karlsson 2003; Hayes et al. 2005).

An important objective of this research was to address the growing need for an in-depth understanding of network capabilities for PSOM. Traditional network theories explain why network actors with diverse motivations forge enduring relationships from economic (Grabher and Powell 2004), sociological (Podolny and Page 1998), or organisational perspectives (Powell 1990; Snow et al. 1992), instead of providing an overall approach practically useful for network design and operations. Strategic management theories recognise the concept of organisational or operational capabilities as a helpful way of synergising resources and activities to achieve competitive advantage (Prahalad and Hamel 1990; Grant 1991; Teece et al. 1997; Barney 1999; Winter 2003) a theme re-enforced in the operations strategy literature (Hayes and Wheelwright 1984; Slack and Lewis 2002; Peng et al. 2008). Extending these concepts to give them a clear focus on the distinctive environment of PSOM will enrich our understanding (Lewis and Brown 2012; Zhang et al. 2014), and address the concern that traditional theories generally failed to address directly the fundamental requirements of PSOM based on relationships, customer interactions, participation and value co-creation (Roth and Menor 2003; Lovelock and Gummensson 2004; Heineke and Davis 2007; Karpen et al. 2012).

Although an analytical framework for network capabilities is still missing in the OM literature, some relevant concepts have been explored in various subject areas, especially in the area of international production. For example, Shi and Gregory (1998) identified five strategic capabilities that differentiate international manufacturing networks from traditional factory focused manufacturing systems. They are the ability to capture required manufacturing resources, the ability to achieve greater efficiency, the ability to deploy and reconfigure resources swiftly, the ability to capture and disseminate internally generated knowledge, and the ability to support individual factories. By studying knowledge flows within an international manufacturing network, Vereecke et al. (2006) identified four types of network units with different roles and capabilities, i.e. isolated plants, receivers, hosting network players, and active network players. The research discussed the evolution and development of network capabilities in different contextual environments. Karlsson and Skëld (2007) conceptualised emerging paradigms of production networks from the aspects of horizontal and vertical technologies. Horizontal technologies are related to product functions that represent product performance characteristics; and vertical technologies are the "pure" technologies in different disciplinary areas. They contended that network capabilities for the future production systems should be founded on specific skills to integrate and combine various vertical technologies into coherent horizontal technologies. At the same time, network dynamics could be interpreted 
through interactions between network actors, resources and actions (Karlsson 2003). In addition to these continuous efforts of exploring potential capability elements in international production networks, there are also studies considering knowledge reuse and integration as organisational capabilities in network operations (Grant 1996; Tiwana and Bush 2005; Singh 2008). It has been believed that operations efficiency can be enhanced by knowledge reuse as replication (Teece 1981; Dyer and Noveoka 2000; Markus 2001). Majchrzak et al. (2004) suggested that knowledge reuse might also contribute to innovation by following a different procedure from conceptualising the problem to searching and evaluating available knowledge, and fully developing reused ideas. There are more explorations which might suggest some possible element of network capabilities, for example in areas of industrial research (Kuemmerle 1997), new product development (Kusunoki et al. 1998), knowledge off-shoring (Kotlarsky et al. 2014) and outsourcing (Youngdahl and Ramaswamy 2008), supply chain management (Choi and Hong 2002), virtual teams and the support tools (Powell et al. 2004), etc. But they hardly ever took network capabilities as a main theoretical perspective in their investigations.

These studies, although individually rooted in some specific operations contexts, may help suggest basic elements to form an analytical framework for network capabilities. In brief, existing studies suggest three generic network capability areas: (1) accessing and deploying dispersed resources (network resources), (2) integrating and coordinating network activities (network coordination), and (3) collective learning and knowledge management (network learning). The first two capability areas confirm the underlying rationale of capability building in the resource-based view (Grant 1991; Barney 1999; Mills and Platts 2003) by combining resources and coordination. The third area reflects the key advantage of network organisations in collective learning (Powell 1990; Foss 1999), and at the same time addresses the need for effective knowledge management in complex network operations (Dyer and Noveoka 2000; Karlsson and Skëld 2007; Zhang et al. 2014).

\section{- Engineering network capabilities for effective value creation}

Value creation in GES focuses on developing and deploying engineering knowledge to provide solutions for and benefit of customers. Zhang and Gregory (2011) suggested possible areas to develop engineering network capabilities for effective value creation around three strategic orientations - efficiency, innovation and flexibility. Efficiency focused network capabilities allow engineers to complete their tasks with fewer resources. Key issues discussed in literature include accessing and sharing global resources (Dyer and Noveoka 2000; Singh 2008), international operations synergies (Birkinshaw and Hagström 2000), continuous improvement infrastructure (Anand et al. 2009), and network structure optimisation (Choi and Hong 2002). Innovation focused network capabilities help GES firms to enhance their competitiveness through providing novel 
engineering solutions. Key issues include exploring and exploiting dispersed knowledge (Kuemmerle 1997; Freel et al. 2009); encouraging creativity and diversity (Hoegl and Parboteeah 2007); cross-region learning (Tiwana and Bush 2005); technology leadership and customer intimacy (Zander 1999). Flexibility focused network capabilities attempt to create value through quick response and adaptation in changing business environments. Key issues include local responsiveness and flexible working approaches (Kotlarsky et al. 2014); resource mobility and virtual teams (Powell et al. 2004); informal/social networks (Hong et al. 2008); strategic outsourcing and risk management (Ellram et al. 2008; Hansen et al. 2013).

Table 1 presents the conceptual framework as a synthesis of the above discussions and provides a theoretical foundation for this research. The framework guided our case studies and suggested directions for data collection/analysis to identify critical network capabilities. In particular, a semistructured interview protocol was developed around the three main network capability areas focusing on resources, coordination and learning, which also served as the main categories in the coding process. GES with various strategic orientations provided different operations contexts in which we were able to understand how these network capabilities were coherently developed for effective value creation.

Table 1. Three main areas of network capabilities

\begin{tabular}{|c|c|c|c|}
\hline \multirow[b]{2}{*}{ Strategic Orientations } & \multicolumn{3}{|c|}{ Network Capability Areas } \\
\hline & $\begin{array}{c}\text { Network Resources } \\
\text { (Accessing and deploying } \\
\text { dispersed resources) } \\
\end{array}$ & $\begin{array}{c}\text { Network Coordination } \\
\text { (Coordinating and integrating } \\
\text { network activities) }\end{array}$ & \begin{tabular}{|c|} 
Network Learning \\
(Collective learning and knowledge \\
management)
\end{tabular} \\
\hline $\begin{array}{l}\text { Efficiency-focused } \\
\text { GES }\end{array}$ & \multicolumn{3}{|c|}{$\begin{array}{l}\text { How do GES firms develop network capabilities to complete engineering tasks with } \\
\text { fewer resources? }\end{array}$} \\
\hline $\begin{array}{l}\text { Innovation-focused } \\
\quad \text { GES }\end{array}$ & \multicolumn{3}{|c|}{$\begin{array}{l}\text { How do GES firms develop network capabilities to enhance competitiveness } \\
\text { through providing novel engineering solutions? }\end{array}$} \\
\hline $\begin{array}{l}\text { Flexibility-focused } \\
\text { GES }\end{array}$ & \multicolumn{3}{|c|}{$\begin{array}{l}\text { How do GES firms develop network capabilities to create value for customers } \\
\text { through quick response and adaptation? }\end{array}$} \\
\hline
\end{tabular}

\section{Research Approach}

We adopted a research approach based on the case study method to empirically enrich and further develop the theoretical constructs of network capabilities for two main reasons. Firstly, although network capabilities are not a totally new concept in the OM literature, in response to reviewer we would like to clarify that prior studies do not seek to cover all important areas of network capabilities. An overall understanding of essential elements of network capabilities for PSOM is missing. It was difficult to develop structured hypotheses to formally test ambiguous and sometimes unknown relationships in complex service settings. The case study approach was therefore appropriate to guide this research around the key theoretical elements suggested from literature and 
develop novel insights (Voss et al. 2002; Yin 2009). We could then possibly avoid a danger of forcing ourselves to provide a precise definition of something unclear or even still non-existent at the point of investigation. In doing so, we could also benefit from the case-based theory building process (Eisenhardt 1989) that was clear enough to guide our intellectual exercises to sort out of valuable insights from scraps of the mind.

Secondly, this research required us to acquire a deep understanding of a vast amount of factors relevant to network capabilities for PSOM. Although the authors were trained as engineers and had earlier industrial experiences in engineering and manufacturing operations, it was still a challenging task for us to quickly apprehend complex network characters, behaviours and new trends of developments in different industrial settings. The case study approach allowed us to integrate information from multiple sources and closely engage with the case companies, and thus gaining an in-depth understanding about network capabilities and their linkages to a broad scope of influencing factors (Stuart et al. 2002; Yin 2009). It was then possible for us to develop a rich vision of different kinds of GES in a relatively short period of time and at the same time maintain an open, but not empty mind to capture important patterns from the case details (Siggelkow 2007).

\section{- Case selection and the unit of analysis}

A multiple case study approach was adopted because it helped to eliminate potential biases, and produced more robust results to reveal the case companies' network capabilities (Meredith 1998; Eisenhardt and Graebner 2007). An initial list of engineering companies was drawn from the OSIRIS database which includes listed and major unlisted/delisted companies of the world, with sector index codes 5413 (for architectural, engineering, and related services) and 5414 (for specialized design services), and supplementary sub-level codes. 50 companies were short listed with three main selection criteria: (1) the companies should have engineering service operations on a global scale; (2) the companies should be perceived as leading players in their particular sectors by three senior industrial fellows of the host organisation and at least one external industrial expert; and (3) the host organisation has contacts of the companies at a proper seniority level to possibly support this research. We studied the websites and the recent annual reports of the shortlisted companies and selected 30 of them who considered global engineering networks as a high strategic priority. The companies were then contacted to request their participation; and 20 companies expressed a strong interest to get involved. After exploratory discussions with these companies to gain a generic understanding of their engineering service networks, 6 of them were carefully selected to provide 3 pairs of cases as recommended by Eisenhardt (1989: p541):

"This tactic [of studying pairs of cases] forces researchers to look for the subtle similarities and differences between cases. This juxtaposition of seemingly similar cases by a researcher looking for differences can break simplistic frames. In the same way, the search for similarity in a seemingly different pair also can lead to more sophisticated understanding..." 
Table 2. An overview of the cases

\begin{tabular}{|c|c|c|c|c|c|c|}
\hline $\begin{array}{c}\text { Strategic } \\
\text { Orientation }\end{array}$ & Case & Sector & $\begin{array}{c}\text { People } \\
\text { (in 2013) }\end{array}$ & $\begin{array}{l}\text { Revenues } \\
\text { (in 2013) }\end{array}$ & $\begin{array}{c}\text { Customer Focus and } \\
\text { Services }\end{array}$ & Unit of Analysis \\
\hline \multirow{2}{*}{$\begin{array}{l}\text { Pair 1- cases } \\
\text { for network } \\
\text { efficiency }\end{array}$} & A & $\begin{array}{c}\text { Railway } \\
\text { engineering }\end{array}$ & 17,000 & $£ 1.7$ billion & $\begin{array}{l}\text { Helping customers to plan, } \\
\text { design and enable capital } \\
\text { programmes that resolve } \\
\text { complex engineering challenges }\end{array}$ & $\begin{array}{l}\text { A network of a few core } \\
\text { centres specialised in } \\
\text { different engineering } \\
\text { areas }\end{array}$ \\
\hline & B & $\begin{array}{l}\text { Automation } \\
\text { engineering }\end{array}$ & 31,000 & $\begin{array}{l}\text { US } \$ 7.7 \\
\text { billion }\end{array}$ & $\begin{array}{l}\text { Providing automation } \\
\text { engineering services for low- } \\
\text { voltage electrical protection, } \\
\text { control and measurement } \\
\text { products and systems }\end{array}$ & $\begin{array}{l}\text { A network of five large } \\
\text { scale engineering centres } \\
\text { to support operations in } \\
\text { over } 40 \text { countries }\end{array}$ \\
\hline \multirow{2}{*}{$\begin{array}{l}\text { Pair 2- cases } \\
\text { for network } \\
\text { innovation }\end{array}$} & $\mathrm{C}$ & $\begin{array}{l}\text { Oil and Gas } \\
\text { engineering }\end{array}$ & 28,000 & $£ 3.9$ billion & $\begin{array}{l}\text { Providing engineering and asset } \\
\text { support services in oil and gas, } \\
\text { mining, clean energy, } \\
\text { environment and infrastructure } \\
\text { markets }\end{array}$ & $\begin{array}{l}\text { A network of eight main } \\
\text { engineering hubs, many } \\
\text { collaborative centres, and } \\
\text { an engineering academy }\end{array}$ \\
\hline & D & $\begin{array}{c}\text { Power } \\
\text { engineering }\end{array}$ & 35,000 & US\$11.0 & $\begin{array}{l}\text { Providing power engineering } \\
\text { services for a wide voltage } \\
\text { range of power generation, } \\
\text { transmission and distribution } \\
\text { equipment/systems }\end{array}$ & $\begin{array}{l}\text { A network of nine lead } \\
\text { engineering centres, } \\
\text { many support centres, } \\
\text { and a global corporate } \\
\text { research centre }\end{array}$ \\
\hline \multirow[b]{2}{*}{$\begin{array}{l}\text { Pair 3- cases } \\
\text { for network } \\
\text { flexibility }\end{array}$} & $\mathrm{E}$ & $\begin{array}{l}\text { Aerospace } \\
\text { engineering }\end{array}$ & 12,000 & $£ 2.1$ billion & $\begin{array}{l}\text { Providing engineering solutions } \\
\text { for civil and military } \\
\text { applications- one of the world's } \\
\text { largest first tier aerospace } \\
\text { services providers }\end{array}$ & $\begin{array}{l}\text { A network of over } 30 \\
\text { independent engineering } \\
\text { centres worldwide }\end{array}$ \\
\hline & $\mathrm{F}$ & $\begin{array}{l}\text { Power } \\
\text { system } \\
\text { solutions }\end{array}$ & 20,000 & $\begin{array}{l}\text { US } \$ 8.4 \\
\text { billion }\end{array}$ & $\begin{array}{l}\text { Providing power system } \\
\text { solutions, including plant } \\
\text { electrification and automation } \\
\text { solutions, bulk power } \\
\text { transmission solutions, and } \\
\text { substations and network } \\
\text { systems }\end{array}$ & $\begin{array}{l}\text { A network of highly } \\
\text { dispersed engineering } \\
\text { resources in over } 100 \\
\text { countries }\end{array}$ \\
\hline
\end{tabular}

We selected the two cases of each pair from different sectors because they face different market demands and industrial norms which would then lead to differences in the process of building network capabilities (Zhang and Gregory 2013). The similarity within each pair was established upon a comparable scale of operations as well as a common strategic orientation as suggested by Zhang and Gregory (2011). A case company's strategic orientation was assessed by exploratory discussions with senior managers, and confirmed by our analysis of its internal documents consisting of operations strategies with help of three sets of indicating keywords. Keywords for efficiency include 'efficient', 'operational excellence', 'cost reduction' and 'waste elimination'. 
Keywords for innovation include 'innovative', 'new technologies', 'novel concepts' and 'creative solutions'. Keywords for flexibility include 'flexible', 'quick response', 'adaptive approaches' and 'tailored solutions'. Companies with a blurred strategic orientation were excluded. By selecting these 3 pairs of cases, we also met Yin's (2009) call for replication logic in case selection. Table 2 presents a brief overview of the cases. The unit of analysis was an engineering service network, which refers to a collection of dispersed engineering resources managed by a focal organisation to complete an engineering task or to achieve a common goal in a collaborative manner. In situations where a company consisted of multiple business groups with very different operational contexts and capability requirements, the engineering service network for a business group was considered as the unit of analysis rather than the parent company.

\section{- Data collection and data analysis}

Data collection and analysis were completed by the authors with support from doctoral researchers and research fellows (see Appendix 1). This allowed the cases to be viewed from the different perspectives of multiple observers, and increased the chances that the researchers viewed case evidence in different ways. For example, in an interview involving two researchers, one researcher who was handling the interview questions had the perspective of personal interaction with the informant, while the other researcher who was taking notes had a more distant and observer's perspective. There was also some practical concern of accessibility which was eased by involving multiple researchers. In some cases only particular researchers could conduct interviews due to security concerns. The same semi-structured case study protocol was used to maintain the consistency in data collection (see Appendix 2). The lead author systematically trained all researchers when they first conducted an interview, including the purpose of this research, the research design and important techniques in using the protocol. The researchers met regularly to review the case data with a view to improving the reliability of the data collection process.

As mentioned above, case data were collected mainly through interviews although these were supplemented by secondary data, e.g. company websites, relevant literature, and company internal documents. Secondary data were used for two main purposes. One was to fill in occasional gaps in developing case narratives based on interviews; and the other was to serve as another data source for triangulation (Yin 2009). Interviewees included managers of group and divisions as well as frontline managers and engineers. All case studies began with an exploratory meeting with senior managers. The meeting was to access the overall strategic orientation of the company's engineering service network and to develop a plan for interviews. The authors would then follow the interview plan and work with informants to understand network capabilities in their engineering services. Additional informants would be nominated creating a snow-ball sampling tactic. In total 64 
informants from the case companies were interviewed, including 13 from Case A, 9 from Case B, 11 from Case C, 9 from Case D, 12 from Case E, and 10 from Case F. About 1/3 of them hold a senior position at the corporate or group level. In addition, we interviewed 12 experts who are familiar with engineering operations of the case companies. An interview would last for about 2 hours on average by following a list of interview questions (see Appendix 2). Interviews were recorded unless participants objected. The transcripts together with a note of the key points were produced and validated by interviewees via emails or telephone afterwards. Once transcripts had been produced we had 487 pages of text (about 190k words). The volume of data for the different case companies varied from 57 to 102 pages of text.

Data analysis began with an inductive process of categorisation guided by Table 1 (Christensen and Sundahl 2001; Radnor 2002). Around the three main capability areas (i.e. Network Resources, Network Coordination and Network Learning), sub-categories were created by searching the interview transcripts/notes, identifying the keywords, grouping them into common themes, and updating the theoretical elements with emerging themes (mainly by the lead author). For example, under the main category of Network Resources, 48 open codes emerged by searching interview transcripts. A tentative set of 13 codes were identified by filtering out all the codes of a frequency count of less than 10 . These 13 codes stand for $64 \%$ of the total frequency. These tentative codes were later merged into 3 mutually exclusive and collectively exhaustive constructs around 'resource consolidation and rationalisation', 'complementary engineering resources', and 'resources colocation'. A theme of 'resource utilisation' was then created to develop a theoretical narrative based on these three groups of capability elements. Themes of 'technology leadership' and 'resource mobility' were identified by following the same data analysis process. Critical network capabilities around 'Network Coordination' and 'Network Learning' were identified by using the same method. This process consisted of constant comparisons between case data and theoretical constructs. Experienced academics and industrial experts reviewed the emerging analysis to enhance the validity of the research (Yin 2009).

\section{Case Analysis}

We began our case analysis by identify critical network capabilities in the companies. To do so we conducted a frequency analysis of key concepts. Table 3 presents the resultant data structured against the categories network resources, network coordination and network learning. 
Table 3- An overview of frequency analysis of key concepts

\begin{tabular}{|c|c|c|c|c|c|}
\hline Main Categories & Sub-categories & Emerged Concepts & Frequency & \multicolumn{2}{|c|}{ Percentage } \\
\hline \multirow{14}{*}{$\begin{array}{l}\text { Network } \\
\text { Resources } \\
\text { ( } 36.3 \% \text { mentions, } \\
414 \text { out of } 1140 \text { in } \\
\text { total) }\end{array}$} & \multirow{5}{*}{$\begin{array}{l}\text { Resource } \\
\text { Utilisation }\end{array}$} & Resource consolidation & 34 & $8.2 \%$ & \multirow{2}{*}{$15 \%$} \\
\hline & & Network rationalisation & 30 & $7.2 \%$ & \\
\hline & & Complementary resources & 57 & $13.8 \%$ & $14 \%$ \\
\hline & & Resource co-location around projects & 26 & $6.3 \%$ & \\
\hline & & Resource co-location around customers & 23 & $5.6 \%$ & \\
\hline & & Technology leadership of key engineering resources & 42 & $10.1 \%$ & \\
\hline & Technology & Leverage expertise & 16 & $3.9 \%$ & $17 \%$ \\
\hline & Leadership & Global engineering leaders/experts & 51 & $12.3 \%$ & $12 \%$ \\
\hline & & Investing in frontier engineering technology areas & 23 & $5.6 \%$ & $6 \%$ \\
\hline & & Resources relocation & 28 & $6.8 \%$ & \\
\hline & & Network restructure & 17 & $4.1 \%$ & \\
\hline & nesuce & Resources dispersion & 20 & $4.8 \%$ & \\
\hline & & Global presence & 16 & $3.9 \%$ & 970 \\
\hline & & Resource assembling/packaging & 31 & $7.5 \%$ & $7 \%$ \\
\hline & & Common working approaches & 56 & $14.8 \%$ & $15 \%$ \\
\hline & Process & Lean engineering & 43 & $11.3 \%$ & $11 \%$ \\
\hline & Commonality & Modular solutions & 23 & $6.1 \%$ & \\
\hline & & Service commoditisation & 15 & $4.0 \%$ & $10 \%$ \\
\hline vetwork & & Technology exploitation/transformation & 41 & $10.8 \%$ & $11 \%$ \\
\hline Cooramation & & Value co-creation & 21 & $5.5 \%$ & \\
\hline (33.2\% mentions, & Process noventy & Customer intimacy & 18 & $4.7 \%$ & $10 \%$ \\
\hline tots & & Guidance for innovation & 28 & $7.4 \%$ & $7 \%$ \\
\hline & & Adaptive working approaches & 52 & $13.7 \%$ & $14 \%$ \\
\hline & Process & Simple/local decision making & 45 & $11.9 \%$ & $12 \%$ \\
\hline & Adaptability & Product/technology transfer processes & 22 & $5.8 \%$ & \\
\hline & & Knowledge transfer processes & 15 & $4.0 \%$ & 1078 \\
\hline & & Good practice sharing & 33 & $8.8 \%$ & \\
\hline & Knowledge & Reuse engineering solutions & 20 & $5.3 \%$ & $14 \%$ \\
\hline & Reuse & Reuse the knowledge of key individuals & 37 & $9.9 \%$ & $10 \%$ \\
\hline Network & & Global standards & 32 & $8.6 \%$ & $9 \%$ \\
\hline Learning & & Eco-system for collaborative learning & 41 & $11.0 \%$ & $11 \%$ \\
\hline (30.4\% mentions, & Knowledge & Innovative working culture & 24 & $6.4 \%$ & \\
\hline 347 out of 1140 in & Creation & Encourage diversity & 15 & $4.0 \%$ & 1076 \\
\hline total) & & Cross-disciplinary learning & 32 & $8.6 \%$ & $9 \%$ \\
\hline & & Digital engineering systems/tools & 49 & $13.1 \%$ & $13 \%$ \\
\hline & Digital Learning & Engineering knowledge network update & 35 & $9.4 \%$ & $9 \%$ \\
\hline & & Virtual reality simulation and system integration & 29 & $7.8 \%$ & $8 \%$ \\
\hline
\end{tabular}




\subsection{Capabilities Elements around Network Resources}

Network resources were the most commonly cited theme (receiving $36.3 \%$ of mentions). Within the category of accessing and deploying resources, three major constructs were identified: (i) resource utilisation; (ii) technology leadership; and (iii) resource mobility.

- Resource Utilisation (increasing the degree of resource utilisation through consolidating and rationalising global engineering resources)

Resource consolidation and rationalisation help the companies to achieve the highest possible degree of resource utilisation. The relevant concepts receive 15\% frequency in our analysis. For example, operational excellence has the highest priority in Case A to maintain and strengthen its global leading position. The company has a few core centres specialised in various areas of railway engineering. These engineering resources support existing and potential projects across business areas, e.g. the company's composite material engineering resources often support multiple railway, aerospace and energy projects in parallel. Similarly, Case B's engineering resources have been consolidated into five large scale engineering centres. These centres support production and markets in over 40 countries by following a common resource allocation approach for efficiency improvement, especially in major engineering areas such as product design and re-engineering, engineering sourcing and procurement, distribution and customer support. This has helped the company to penetrate into global distribution channels through rationalised engineering offerings and central coordination. The head of global engineering supply explained the rationale behind this

- "We have about 50 customers with a global contract. The number will be over 60 by the end of this year, and more in the future... The reason [for having more global contracts] is to reduce resource duplication and repetition. That was a serious problem because we had to manage a lot of individual contracts [over 16,000 contracts at the time of interviewing]. Customers will benefit too..."

Alongside these concentrated engineering resources (either physically at a few locations or virtually around a small number of customers), complementary resources to complete a complex engineering project are secured through collaboration with local contractors/partners (the relevant concepts receive $14 \%$ frequency). Trusted partners are often involved very early from the bidding and preparation stage of a project to make sure that an engineering network as a whole has sufficient resources to complete the engineering tasks and at the same time these resources can work together efficiently throughout the project lifecycle. For example, in a railway station renovation project in UK West Midlands, Case A's engineers are co-located with employees from the rail infrastructure provider and local construction contractors in the same building nearby the project site. In the main engineering office, engineers from all the partners have to walk through a project dashboard to access their working areas or meeting rooms. This dashboard displays the real time progress of key 
engineering tasks. An engineer reporting directly to the project leader is responsible for communicating to all the partners and updating the dashboard twice a day. The purpose of this colocation of engineering resources and the workplace layout design is to improve communication between engineers, which allows the engineering network to operate seamlessly and efficiently to deliver the best solution to meet customer requirements. The frequency received by concepts relevant to resource co-location is $12 \%$.

- Technology Leadership (maintaining technology leadership of key engineering resources)

Technology leadership of key engineering resources helps companies to enhance their competitiveness worldwide. The relevant concepts receive $10 \%$ frequency in our analysis. For example, Case $\mathrm{C}$ enjoys a good reputation for technical excellence and customer focused innovation. Its innovation capabilities are highly trusted by customers around the world and respected by competitors. Its engineering resources are organised into engineering centres (or hubs) to develop and maintain technology leadership of key engineering resources. These leading engineering resources are made available to the whole company via an integrated work share and technical performance management system centred around eight regional hubs to support worldwide project execution (concepts relevant to leverage expertise receive $4 \%$ frequency). Driven by the long-term rise in energy demand and increasing environmental pressures, these key engineering resources are shifting toward more frontier and deep-water developments to provide novel engineering solutions for customers in three main areas. First is to reach as much oil and gas as possible with new extracting technologies and more advanced production facilities. In general, oil and gas resources are increasingly difficult to extract, and the projects have become larger and more complex. The company has developed strong expertise and global experience of delivering large and complex engineering projects in harsh locations. It can help customers to reach deeper into reservoirs and help them to recover oil and gas from hard-to-reach corners of the reservoirs. Second is to find new ways of developing unexploited oil and gas. A large portion of the world's proven energy reserves are in remote locations without cost-effective transport to market. Its engineers have to help customers to cope with technical challenges in harsh locations including hostile climatic conditions, Arctic environments, extreme temperatures, earthquake-prone regions, or high wave conditions. Third is to develop plants producing clean energy. The company has strong nuclear engineering resources developed over 50 years and works at the forefront of new energy technologies. A cross utilisation of such leading knowledge allows the company's oil and gas engineers to offer innovative solutions for producing clean, high performance fuels.

Similarly, Case D has successfully maintained its global leading market position for decades through technology leadership and enhancing customer value. The company has recently been 
named by MIT among top 50 innovators of the world. Its engineering resources have been structured into centres with leading and supporting roles. A lead centre often possesses strong expertise in some core technology areas and is responsible for further developing engineering expertise and making it available world-wide. To maintain global leadership of these key engineering resources, a lead centre works closely with corporate research laboratories of the parent company, leading universities and research organisations world-wide (investing in frontier engineering technology areas receives $6 \%$ frequency). A support centre's role is to support lead centres in creating engineering solutions and carry out some design localisation or order-based modification work. Many support centres are collocated with production/project sites to support existing businesses and quickly ramp up new services and solutions. These centres operate closely with local markets for medium term innovation initiatives.

Leading engineering expertise of these companies can be accessed from anywhere via global innovation programmes or through engineering academies. A manager explained the reason behind this- "Their [global leading experts'] importance is tremendous. Their participation internally added confidence in our engineering team, and externally secured critical deals. To say it without any exaggeration, many clients signed on the dotted line simply because they saw some famous names in our team". To develop and retain these experts, employees are motivated to engage with the case company and commit to its success through various shared ownership schemes (concepts relevant to development and retaining global engineering leaders/experts receive $12 \%$ frequency). To address problems of skills shortage or aging engineering experts in some regions, the case company has developed strategic plans for attracting skilled engineers (particularly those with experiences in successful delivering complex projects), improving graduate and trainee recruitment, and educating schoolchildren about careers in engineering.

- Resources Mobility (mobilising engineering resources to cope with changing customer needs and uncertainties)

Resource relocation and restructure (the relevant concepts receive $11 \%$ frequency) help companies to cope with changing customer needs and uncertainties. Case E's engineering resources are dispersed with customer bases, technology centres, and production facilities around the world. These resources form independent centres of excellence that are mainly responsible for local businesses, with the central corporate function reviewing their performance quarterly and the technology committee overseeing long term capability development. These resources are regularly switched between projects and business areas. Such resource relocation (or rescheduling) takes place unnecessarily in a physical form because many engineering tasks can be completed from a remote location. In occasions that physical relocation is required, the company follows a principle 
of using local (or nearest) engineers to work on a project. Thanks to the long planning lead time of an engineering project, the company is able to provide comprehensive training programmes for engineers when they need new skills to complete the project work.

Engineering resources in Case $\mathrm{F}$ are also highly dispersed with local markets to enhance customer relationship and provide more value adding services for them (concepts relevant to strategic resources dispersion and global presence receive $11 \%$ frequency). The company disperse these resources strategically to complete some specific engineering tasks for three main reasons. Firstly, power systems are heavy, big and facility specific; and therefore are difficult to be shipped around the world. The company has to deploy its engineering resources in a very flexible manner to support these products at where they are. Secondly, its engineers have to respond to customer requirements quickly and often in emergency to avoid disastrous consequences. Thirdly, its engineering solutions have to meet local government legislations and within many other operational constraints. The company must be able to assemble a set of relevant engineering know-how very quickly and adapt them to some particular local requirements (concepts relevant to resource assembling and packaging receive $7 \%$ frequency). Although these reasons are self-explicit and apparent in many projects, its global engineering director reminded the authors that resource mobility decisions are not always straight forward- "Our senior management team had different opinions on investment plans in China... We finally decided to scale up the local engineering capabilities after long debates. But Chinese markets were slowing down later. We are chained to these heavy investments... We of course can use our engineering resources in China to support international markets. The problem is that we want to maintain engineering capabilities in other countries too. We don't have enough work for them [i.e. engineering centres in China], and the total cost [of using Chinese engineering resources to support international markets] is much higher than that people think... ".

\subsection{Capability Elements around Network Coordination}

Coordinating and integrating network activities were another core theme as we expected (receiving $33.2 \%$ of mentions). Underlying the broad theme of network coordination, three sub-themes emerged: (i) process commonality; (ii) process novelty; and (iii) process adaptability.

- Process Commonality (establishing common working approaches in main service categories)

Cases A and B align complex engineering services activities with common working approaches across regions and businesses (the relevant concepts receive 15\% frequency). Such approaches enable engineers to provide optimal solutions to address some common problems collectively and disseminate these solutions throughout engineering networks in a view to avoiding duplication and waste elimination. Railway engineering projects in Case A often struggle with an ever increasing level of complexity and mounting costs as small issues evolved into bigger and more significant problems due to the evolution of engineering design, customer changes or operational changes. The company has continuously invested in developing common engineering 
processes based on the lean engineering concept (the relevant concepts receive $11 \%$ frequency), as a senior manager said: "Railway construction costs have been doubled in the recent years. This gives us room for efficiency improvement. We have embraced LEAN because it helps us to simplify complex operations- [in our businesses] simplicity equals success... It took us a lot of time and effort to establish the right LEAN processes - the working process itself is a technology". To develop and implement these common processes, the company involves all the partners by empowering them and getting them involved in the design and delivery process. The aforementioned engineering project dashboard adopted in this company has been virtually visualized by 3D computer models in many projects. The project leader who is in charge of the West Midlands railway station project also supervises overseas projects in Mideast on lean engineering. Well defined performance indicators focusing on operational efficiency alongside safety in the workplace and on project sites have been used to measure the past performance and also provide information and context for forward plans, e.g. volume, secured workload, capacity utilisation, etc.

In a different context, engineering services in Case B are increasingly commoditised and delivered in large volumes. Concepts relevant to modularity and service commoditisation receive $10 \%$ frequency. Driven by competition pressures from low cost countries, the case company is seeking greater efficiency through international operations synergies and joint problem solving. Global business groups coordinated its engineering activities for efficiency improvement. These groups are fully responsible for defining operations targets, monitoring costs and investment, coordinating production, developing business strategy, managing intellectual property, licensing agreement, and supply chain management. Global engineering activities have been brought together with crosscompany standards and common working procedures. This allows engineers to share the same rigorous standards, accountability and good engineering solutions worldwide. Commoditised/ modular solutions are developed and adopted across all the business groups. A committee formed by high-level experts from the whole company takes the responsibility of identifying engineering processes that should be developed as core and common across main business groups.

- Process Novelty (generating novel engineering solutions through value co-creation)

Concepts relevant to technology exploitation and quickly transforming new technologies into novel engineering solutions receive $11 \%$ frequency. Innovation processes in Case $\mathrm{C}$ focus on value co-creation with customers by enabling engineers to identify the best way to maximise the value of their expertise to customers. The company helps customers to design, deliver and maintain their strategic and complex assets, and offer through-life asset support from feasibility planning to decommission. It has a strategic vision to inspire trust and loyalty in customers by continuously delivering innovative solutions and excellence through close collaboration and long-term relations. 
Value co-creation with customers becomes a core value and provides a cultural context in which engineers work (the relevant concepts receive $10 \%$ frequency). Some long-term customer relationships are on a global scale, e.g. the company signed a global offshore agreement with a key customer in 2008. A series of large scale engineering projects have been developed and implemented under this agreement and a lot of them are original, revolutionary and first-of-a-kind work. This provides an effective way for the customer to quickly benefit from new technologies or novel concepts of operations.

Coordination in Case D relies on a set of guidelines for reference in key engineering areas, such as global engineering design and business evolution management. This provides useful guidance for the often fuzzy and risky process of innovation (concepts relevant to innovation guidance receive $7 \%$ frequency). An engineering manager explained how innovation guidance works in his company - "A very important part of my job is to bring new technologies into our different business areas. It is a complex and long process. My team members come from different countries and most of them have a PhD degree, have to work together with front line operations for years to realise the potential of some new technologies..." Clearly defined criteria are used to evaluate an engineering project at a set of critical stages, e.g. idea generation, business case development, conceptual design, detailed design, trial production, launch to market, etc. Projects failing to meet the evaluation objectives will be reviewed in further details or terminated. By following these guidelines, one engineering centre will lead a new product/service development project and assign sub-tasks to support centres with appropriate capabilities. Eight business groups coordinate engineering activities. Each has a group manager responsible for business portfolio management, lifecycle management and value improvement; and a technology manager responsible for product/service development. Driven by increasing global competition, the case company is experiencing a major strategic transformation for sustainable success with new markets and innovation. Existing designs and engineering solutions are transformed, for example simplified or updated with new technologies, to maintain technology leadership and at the same time to offer competitive prices for emerging markets.

- Process Adaptability (adopting adaptive processes through close engagement with customers) Concepts relevant to adaptive working approaches receive 14\% frequency. Case E has to cope with changing customer needs and uncertainties in the aerospace industry. The case company has developed a full range of adaptive and pro-active working approaches for different kinds of business environments, e.g. on-site work, package work, integrated solutions, design and build, strategic relationships, dedicated and collocated teams, joint teams, or partnerships. These engineering processes are often based on close engagement and interaction with customers; supported by rigorous risk management techniques, and facilitated by smart modelling and 
simulation tools. Simple performance metrics are used to assess current operations and to predict future trends. Local decision-making is encouraged with some central influence to improve local responsiveness and agility (the relevant concepts receive $12 \%$ frequency). In a new engineering project, particularly at the early stages to develop conceptual solutions, multi-skilled engineers work closely with customers, often at customer bases, to make sure that customer requirements are well understood and conceptual solutions are worked out quickly and effectively. An interviewee introduced the case company's ongoing transformation towards quicker and simpler decision making from the perspective of engineering supply chains: "Safety and risks are important for us. Our old supplier selection approach was complex, sophisticated, robust, but slow. We had to say no to good opportunities when we were waiting for a decision to be made. We are now moving toward a 'fit-for-purpose' approach. It is quicker and simpler... We don't have to make any compromise in safety or risks because this ['fit-for-purpose'] approach is supported by a large database and deep engineering knowledge. Computers will do complex analysis automatically. "

In a different context, network coordination in Case F has to cope with an increasing demand for localisation and customisation driven by the rapid growth of emerging or new markets. Regular technology and knowledge transfer becomes a normal part of day-to-day operations within the company's engineering network (the relevant concepts receive 10\% frequency). Local business groups coordinate engineering activities. Each group, often co-located with an engineering centre, has its own technology manager, quality manager, operations manager, marketing manager and business manager. These managers, most of whom are engineers, are responsible for the business group's overall strategies. These engineering centres are responsible for local business development. With a strong brand name and a wide range of global leading engineering expertise, these centres can provide services for high voltage power systems installed by different makers or even by its competitors with market prices. Group managers review the performance of these local centres quarterly. Proposals from local centres will quickly go through an efficient review and decision making process based on a check list of key information. This allows engineers working closely with customers to improve local responsiveness and operations flexibility.

\subsection{Capability Elements around Network Learning}

Another core theme for the companies was collective learning and knowledge management (receiving $30.4 \%$ of mentions). Three sub-themes emerged underlying the broad theme of network learning: (i) knowledge reuse; (ii) knowledge creation; and (iii) digital learning.

- Knowledge Reuse (establishing effective mechanisms for knowledge reuse)

Effective mechanisms for good practice sharing and reuse support network learning across regions and business areas and avoid repeating the similar work (the relevant concepts receive $14 \%$ frequency). A chief engineer of Case A articulated the importance of knowledge 
reuse in his company - "The success of our company is determined by how good we are in reusing high value engineering knowledge within our company and with our clients. A simple way [to achieve this] is to have large groups of junior associates to support senior engineers. Junior colleagues work with clients closely, and senior engineers will get involved only at certain critical stages for example to sign a deal, to conceptualise a solution, or to close a project... Roughly speaking, the ratio [of the number of junior to senior engineers in an engineering project] is about 10 to 1 in the UK, and 20 to 1 or higher in India or China". This allows the company to capture the knowledge of key individuals and make such valuable knowledge accessible to the whole company and to be reused by multiple projects (the relevant concepts receive $10 \%$ frequency). To facilitate knowledge reuse, each senior engineer has an iPad linked to a cloud of engineering issues and enquiries. This allows engineers with relevant experiences to provide comments or suggestions on urgent matters at any time or place, e.g. in a taxi or when they are waiting for a train. At the same time, the company encourages its engineers to reuse existing solutions to avoid time wasted repeating the similar work. A common working language, a common set of engineering tools, and controlled visibility of multidiscipline data are vital to continual efficiency improvement of engineering services.

Standards are another mechanism to support knowledge reuse (receiving 9\% frequency). Case B has a range of well-established global engineering standards and the supporting knowledge management systems to achieve world-class operational excellence, including design for manufacturing and assembly (DFMA), manufacturing IT, industrial IT and eBusiness solutions. DFMA methods are embedded in engineering tools and techniques. Manufacturing IT allows materials to move between workstations, factories and suppliers continuously and quickly. Industrial IT increases the standardisation of products as basic building blocks for larger solutions. eBusiness solutions provide an efficient online system for customers and suppliers. Commonality models and modular engineering solutions allow its engineers to capture and reuse high value engineering knowledge across the network by effectively facilitating co-operation between engineers around the world. Such proactive measures contributed to cost savings over US\$80 million in 2013, about one third from operational excellence initiatives and two thirds from global engineering value chain optimisation.

Network capabilities for knowledge reuse focus on various aspects for different kinds of engineering activities although some generic documentation and project review tools have been commonly adopted by the companies. Research and technology focused engineering activities support knowledge reuse via informal networking and social events. For example, dedicated budgets for social events would be secured even in financial constrained situations, and teams of engineers would travel to different countries and stay there for months (and sometimes for years) to apply research outputs in frontline operations. Design and development focused engineering activities tend to adopt knowledge based engineering tools, i.e. engineers can combine and choose 
from sub-packages or modules to resolve their problems rather than doing everything from the scratch. Engineering knowledge has been reused in the sense of packaging these solutions and providing step-by-step guides to use them. Maintenance and support focused activities rely on welldeveloped standards and continuous improvement platforms for knowledge reuse. In addition to refining company-wide standards, the companies are active in influencing industrial/international standards. An extreme example was that engineers sometimes had to support engineering systems installed in decades ago when the technologies and demands were very different from the current operations context. Standards helped engineers to relearn critical engineering knowledge and bring their solutions update to date.

- Knowledge Creation (providing an eco-system for knowledge creation)

An eco-system for collaborative learning with a wide range of partners speeds up the transformation from innovative ideas/technologies to marketable services/solutions (the relevant concepts receive $11 \%$ frequency). Based on long-term relationships with key partners, Case $\mathrm{C}$ has developed an eco-system for knowledge creation and collaborative learning with customers, contractors and independent research organisations. This provides an innovative working culture by encouraging creativity and diversity, learning across disciplines and businesses, and allowing a certain degree of risk taking (the relevant concepts receive $10 \%$ frequency). The director of engineering capabilities explained why an eco-system of knowledge creation is important - "We provide the best design in advanced engineering sectors. Both our engineers and our clients know this very well. We have developed close links with best research centres of the world to maintain a pool of global leading technologies and expertise... This is why we can always provide innovative solutions for our clients." This collaborative learning system contributes to a boundary-less alliance to tackle some complex engineering challenges. The company recently completed a project involving three partners who have worked together for over 30 years. This project became a benchmarking example for collaborative innovation not only in the global oil and gas industry but also for other industries. In 2013, the company launched a restructuring programme to promote collaboration with customers by simplifying decision-making and working across the company to deliver integrated services to customers, as a senior manager explained - "our focus on our customers and our people will continue... Our goal is to be a trusted partner: the supplier of choice for our customers; the employer of choice for our people..."

Network learning in Case D has been based upon a global platform of knowledge creation supported by sub-systems and modules for enterprise resource planning (ERP), customer relationship management, and virtual engineering offices to provide an open working environment for engineers to work together from different time zones. The engineering platform has eight replication sites to improve the speed and effectiveness in supporting globally dispersed engineering 
activities. Customers engage with the company through a dedicated single interface connected to the platform. This helps to speed up the process of capturing customer needs and generating novel solutions based on modules or sub-solutions available in the company's global engineering network. In addition, network learning may not be limited within the eco-system of customers, suppliers and partners in the same industry, and find inspiration in some unlikely place. Concepts relevant to cross-disciplinary learning receive $8 \%$ frequency. An interviewee commented: "An entrainment company [SONY Entertainment] caught our attention in an exercise to improve customer satisfaction and boost innovation. It's nothing to do with power or automation engineering at all. It's to do with service design. That is the kind of thinking we need to bring in our company to drive innovation and customer satisfaction".

- Digital Learning (developing digital engineering learning systems and remote working tools)

Digital learning systems and powerful remote working tools allow engineers working together continuously around the clock and follow the sun (the relevant concepts receive 13\% frequency). Network learning in Cases $\mathrm{E}$ has been very well supported by information and telecommunication technologies (ICT). Such digital systems enable the company to quickly restructure its engineering network by acquiring external engineering knowledge and integrating them into its global network. Acquired engineering centres, which usually possess unique knowledge or expertise, will join Case E's engineering network as new centres of excellence after re-organising (or relocating) their resources and connecting them into the company-wide engineering knowledge management system. The new centres operate autonomously with their knowledge accessible to the other centres via the central engineering portal. Concepts relevant to updating engineering knowledge network receive $9 \%$ frequency.

Case F has its own intranet for data and engineering knowledge management. This provides an effective virtual learning environment. Its engineers can directly acquire data from any centres around the world. At the same time, the company has an engineering solution configuration platform linking together internal and external partners around the world. The platform is supported by a virtual reality simulation system (i.e. a power grid system) for system integrators who are treated as internal units with direct access to its engineering knowledge network (the relevant concepts receive $8 \%$ frequency). It helps to create and manage engineering knowledge for maximum total value for customers along the project lifecycle. A lead engineer explained how this platform works: "[on this platform] we can easily specify customer needs and restructure our supply chains to deliver new services faster than our competitors. We don't do everything by ourselves. We work with suppliers to enhance our engineering capabilities. We talked about YY [an IT company specialised in plant design] earlier-we can easily integrate YY's latest plant designs into our solutions for clients... We are seriously considering business module innovation in big-data environment..." 
However, there is also a more reserved view about technology or its impact on engineering services, as commented by an interviewee - "I don't understand why people get so excited about these things [e.g. cloud services, big-data, new IT applications, devices, etc.]. We use these things all the time. They are nothing new to me. They are there to support our engineers. It is capable people that create great solutions for our clients and underpin our success in the past and in the future... Don't get me wrong. I am not against new technologies. I use these things myself [pointing to his latest model iPhone on desk]. What I want to say is that people are the most valuable asset in our businesses."

\subsection{A Summary of the Key Findings}

Table 4 presents key insights from case analysis with the resource-coordination-learning model of network capabilities. It further develops the conceptual framework (Table 1) by identifying critical network capability elements and indicating how these capabilities have been coherently developed for effective value creation in different operations contexts. Managerial implications are also suggested for GES firms seeking to cope with operational challenges and opportunities in complex global service networks. 
Table 4. The resource-coordination-learning model of network capabilities and insights from case analysis

\begin{tabular}{|c|c|c|c|}
\hline k Capabilities & Pair 1- Cases A \& B for Network Efficiency & Pair 2- Cases C \& D for Network Innovation & Pair 3- Cases E \& F for Network Flexibility \\
\hline $\begin{array}{l}\text { Network Resources } \\
\text { (Accessing and } \\
\text { deploying dispersed } \\
\text { resources) }\end{array}$ & $\begin{array}{l}\text { Resource Utilisation } \\
\text { - Consolidating and rationalising engineering resources for } \\
\text { maximum utilisation } \\
\text { - Securing complementary engineering resources through } \\
\text { network collaboration } \\
\text { - Co-locating engineering resources (physically or virtually) } \\
\text { for effective communication } \\
\text { Implication: } \\
\text { The traditional partnership management (PM) suffers from a } \\
\text { high degree of resource duplication and thus a low degree of } \\
\text { utilisation. An engineering service network improves resource } \\
\text { utilisation through economies of scale and scope across } \\
\text { locations/regions. }\end{array}$ & $\begin{array}{l}\text { Technology Leadership } \\
\text { - Maintaining technology leadership of key engineering } \\
\text { resources and leveraging key expertise worldwide } \\
\text { - Developing and retaining global engineering leaders } \\
\text { /experts } \\
\text { - Investing in frontier engineering technologies } \\
\text { Implication: } \\
\text { PM nurtures and supports local champions in various } \\
\text { engineering areas of a subsidiary. An engineering service } \\
\text { network develops global engineering leaders for the whole } \\
\text { organisation. }\end{array}$ & $\begin{array}{l}\text { Resource Mobility } \\
\text { - Mobilising resources regularly to meet changing } \\
\text { customer needs } \\
\text { - Restructuring resources strategically to cope with } \\
\text { uncertain business environments } \\
\text { - Assembling resources swiftly to provide a complete } \\
\text { engineering solution } \\
\text { Implication: } \\
\text { A typical engineering centre in PM attempts to serve local } \\
\text { customers with its own resources. An engineering service } \\
\text { network provides customers with the best possible solution } \\
\text { by accessing and deploying global engineering resources. }\end{array}$ \\
\hline $\begin{array}{l}\text { Network Coordination } \\
\text { (Coordinating and } \\
\text { integrating network } \\
\text { activities) }\end{array}$ & $\begin{array}{l}\text { Process Commonality } \\
\text { - Establishing common working approaches in main service } \\
\text { categories } \\
\text { - Providing commoditised engineering solutions for } \\
\text { businesses around the world } \\
\text { - Improving clarity and visibility of engineering processes by } \\
\text { adopting lean approaches } \\
\text { Implication: } \\
\text { PM promotes informal coordination, lacking of structured } \\
\text { processes. An engineering service network provides common } \\
\text { working approaches across the world. }\end{array}$ & $\begin{array}{l}\text { Process Novelty } \\
\text { - Generating novel engineering solutions through value co- } \\
\text { creation with customers/partners } \\
\text { - Quickly adopting technologies to develop and improve } \\
\text { services } \\
\text { - Providing useful process guidance for engineering } \\
\text { innovation } \\
\text { Implication: } \\
\text { PM supports innovation through ad-hoc initiatives. An } \\
\text { engineering service network provides a systematic structure } \\
\text { to support innovation. }\end{array}$ & $\begin{array}{l}\text { Process Adaptability } \\
\text { - Adopting adaptive working through close engagement } \\
\text { with customers } \\
\text { - Encouraging simple, local decision making with light } \\
\text { central influence } \\
\text { - Establishing effective processes for technology/ } \\
\text { knowledge transfer and risk management } \\
\text { Implication: } \\
\text { International coordination in PM relies on a small number } \\
\text { of senior partners. An engineering service network } \\
\text { encourages autonomous decision making with effective } \\
\text { central coordination in strategic areas. }\end{array}$ \\
\hline $\begin{array}{c}\text { Network Learning } \\
\text { (Collective learning and } \\
\text { knowledge management) }\end{array}$ & $\begin{array}{l}\text { Knowledge Reuse } \\
\text { - Identifying good engineering practices/solutions and } \\
\text { reusing them across different service areas } \\
\text { - Capturing the precious knowledge of key individuals and } \\
\text { making it available worldwide } \\
\text { - Using global standards (developed by the organisation) to } \\
\text { facilitate knowledge reuse } \\
\text { Implication: } \\
\text { PM relies on professional bodies/societies for knowledge } \\
\text { reuse and sharing. An engineering service network develops } \\
\text { internal mechanisms/standards for knowledge reuse and } \\
\text { sharing. }\end{array}$ & $\begin{array}{l}\text { Knowledge Creation } \\
\text { - Providing an eco-system for knowledge creation and } \\
\text { collaborative learning } \\
\text { - Promoting an innovative working culture by encouraging } \\
\text { creativity/diversity and pursuing perfection } \\
\text { - Encouraging cross-disciplinary learning to generate novel } \\
\text { engineering solutions } \\
\text { Implication: } \\
\text { PM in general lacks a supportive environment for creating } \\
\text { new knowledge and novel solutions. An engineering service } \\
\text { network provides a global system for knowledge creation } \\
\text { and improving consistency in operations. }\end{array}$ & $\begin{array}{l}\text { Digital Learning } \\
\text { - Developing digital engineering learning systems and } \\
\text { remote working tools to support engineers worldwide } \\
\text { - Updating engineering knowledge networks through } \\
\text { regular mergers and acquisitions } \\
\text { - Using virtual reality simulation to support system } \\
\text { integration and maximise total value for customers } \\
\text { Implication: } \\
\text { PM sometimes holds a reserved view toward new } \\
\text { technologies/ tools. An engineering service network is keen } \\
\text { to take pro-active approaches to benefiting from digital } \\
\text { learning and new information and data management } \\
\text { technologies. }\end{array}$ \\
\hline
\end{tabular}




\section{Discussion}

\subsection{What Can PSOM Learn from GES?}

We have identified critical network capabilities for GES. The implications for PSOM are two folds(i) the network capability model provides a useful theoretical lens that can effectively explain the evolving organisational features of PSOM in the current operations contexts; and (ii) the case studies suggest important strategic decision areas to address the key research issue of managing and supporting network groups to achieve organisational objectives in PSOM (Heineke 1995).

Firstly, this paper provides an analytical framework for OM scholars to understand operational challenges of PSOM in transformation towards global service networks (Brock et al. 2007; Malhotra and Morris 2009). Originality in strategic operations consists often in making clear what was not clear before or synthesising novel practice/new developments in a useful way, rather than in inventing a non-existent theory or concept. From this point of view, this paper contributes to the PSOM literature in general by identifying critical capability areas (i.e. resources, coordination and learning) for service networks and indicating their linkage to high-level strategic priorities (e.g. efficiency, innovation or flexibility). The theoretical model helps bring together fragmented research efforts around network capabilities for PSOM. For example, Heineke (1995) noticed "network models" of physicians groups that provide flexible healthcare options for customers; Moor and Birkinshaw (1998) suggested centres of excellence as a "structured approach" to knowledge management in the often loose and informal organisations of global services firms; Goodale et al. (2008) reported "network alliances" as the organisation form that facilitates both entrepreneurial individuals and collaborators in PSOM; and Wagner et al. (2014) suggested that "institutional mechanisms such as networks" are necessary to grant access to external learning in professional service firms. In doing so, the model leads to an overall understanding of network capabilities for PSOM which can more clearly articulate this research direction of increasing importance and establish a solid ground for further developments (Kusunoki et al. 1998; Choi and Hong 2002; Coltman and Devinney 2013).

Secondly, our case studies provide specific examples of critical strategic decisions of PSOM from a network perspective as well as an in-depth understanding of how to compete in such operations contexts through building network capabilities. These examples support Heineke's (1995:p256) observation of the changing importance of strategic decisions in PSOM. At the same time, the cases suggest possible directions of improvement in PSOM, which not only reflect the traditional strategic orientations in OM such as leanness for greater operations efficiency (Shah and Ward 2003) and agility for greater flexibility (Narasimhan et al. 2006), but also address more recent developments to promote innovativeness through establishing supportive operations capabilities 
(Hayes et al. 2005; Droege et al. 2009; Harvey 2011). Supported by such an in-depth understanding of how to compete through building network capabilities, we are able to confirm Coltman and Devinney's (2013) argument that substantial gains could be achieved by properly aligning a service firm's operational capabilities with customer needs, i.e. by orchestrating the three main areas of network capabilities (i.e. resources, coordination and learning) for effective value creation with (and for) customers in a particular service setting.

In addition, this paper extends the previous studies on global engineering networks which were based on observations of engineering operations for manufacturing (Zhang and Gregory 2011; Zhang et al. 2014). Our case studies confirm that a sequential view of the engineering value chain might not be instantly recognisable in GES. The network capability model will thus be helpful because its three main areas of analysis (resources, coordination and learning) can comfortably span across functional and organisational boundaries in a complex services network. Beyond the strategic goals suggested by Zhang and Gregory (2011 \& 2013), professional services firms will be able to address other operations priorities by combining these three sets of capability elements in a systematic manner.

\subsection{What Can Managers Learn from Our Studies?}

Our case studies suggest GES firms building network capabilities by combining resources, coordination and learning on a global scale, particularly in high value engineering areas which are increasingly important for their future success in global competition. Such capabilities, based on advanced engineering technologies and knowhow embedded in developed economies, have potentials for value co-creation with partners worldwide. To build effective network capabilities in high value engineering areas, managers in the aspect of network resources should recognise opportunities in rationalising global engineering resources, developing worldwide engineering leaders, and providing the best possible solution for customers with global resources. In the aspect of network coordination, our case studies highlight the importance of establishing common working approaches in key engineering areas, providing a supportive working environment for innovation, and leaving necessary space for autonomous decision making. In the aspect of network learning, we would like to encourage managers to promote knowledge reuse with standards, create an ecosystem for knowledge creation, and benefit from digital learning and new technologies.

Our theoretical model can be used to assess network capabilities of professional service firms. To do that, managers are suggested to begin with developing a structured network capability assessment matrix based on the key capability elements in areas of resources, coordination and learning. This matrix should be adapted to address the particular situation of a focal firm, i.e. the capability elements should be interpreted in explicit terms familiar to its managers. The firm can 
then use the matrix to assess network capabilities in its main business areas. Dedicated facilitators are strongly recommended to maintain consistency in the plan and execution. An overall network capability profile will eventually be generated by aggregating results from main business areas. This working approach can be employed to facilitate managers to understand the current capability profiles of their global services networks, or to guide them to restructure their global services networks to achieve desired capabilities for effective value creation. Another huge benefit is that this exercise will help establish a common vision of the firm's strategic objectives and develop coherent capabilities to achieve them through global network operations.

\subsection{Directions for Future Research}

It has been expected that this research will lead to a novel analytical framework in a relatively unexplored, multi-disciplinary field such as service network operations on a global scale. Besides further testing the network capability model with large scale empirical data, limitations in the research scope would suggest some directions for future research. The case studies were mainly focused on network operations that are owned, controlled or managed by the focal case companies, i.e. network operations with clear leadership. For those network operations based on collaborations of multiple organisations of different sizes, network boundaries become more ambiguous, and the issues about limited trust, power conflicts and lack of a shared identify will gain higher importance than in-house operations (Matos and Afsarmanesh 2004; Ahuja et al. 2007; Freel and de Jong 2009). A proper understanding of network dynamics will be critical because each project may have a different set of network members. New capability elements or organisational features may emerge. Further studies are therefore required to understand the distinctive features of such open, dynamic, collaborative networks. A similar research approach can be adopted although some adaptation might be necessary to reflect the specific requirement of inter-firm collaborations. A potential problem could be the aggregation process to generate an overview of the whole network based on data from individual network members, because individual network members may hold very different views about their network contexts and the desired capabilities.

Identifying generic network strategies for professional services or suggesting cross-category network archetypes (von Nordenflycht 2010) will provide another key area for future research. Such network archetypes, with typical capability profiles and strategic orientations, could be useful reference models for managers to optimise their current service networks or design new networks. Large scale empirical studies are required to explore generic patterns which may possibly exist. In searching for such network archetypes, our case studies can be usefully summarised into potential research hypotheses to be further developed and tested. This will allow researchers to draw 
common conclusions that are more helpful for the design and operations of global servicing networks in a particular situation.

We have suggested identifying differences between leading companies and poor performing companies for further testing the robustness of the theoretical model. This will lead to a fruitful research area alongside large scale empirical studies. The pervasive use of information and communication technologies and the increasing popularity of digital learning in engineering services would also suggest an interesting research area. For example, in the case studies, a number of senior managers did talk about their wish to simulate or visualise network capabilities for the purpose of improvement and optimisation.

\section{Conclusion}

This paper identifies critical network capabilities for GES and provides an analytical framework of building global capabilities for PSOM through case studies in specific settings of engineering. Grounded in the existing literature, the framework presents network capabilities for PSOM in three main areas: (1) accessing and deploying dispersed resources, (2) coordinating and integrating network activities, and (3) collective learning and knowledge management.

This research contributes a step further towards a generic understanding of network capabilities for PSOM on a global scale. The cases of global engineering services throw light on a network perspective of professional services by bridging and extending the existing literature on network organisation structures and by suggesting possible areas of strategic alignment between network capabilities and effective value creation in PSOM. The research findings can help managers to build effective network capabilities for global competition by better understanding their current network capabilities, identifying capability areas of strategic importance, and restructuring their global service networks to achieve desired capabilities.

\section{Reference:}

Abdelzaher, D.M. 2012. The impact of professional service firms' expansion challenges on internationalisation processes and performance. The Service Industries Journal 32(10), 1721-38.

Ahuja, G., Soda, G. and Zaheer, A. 2007. The genesis and dynamics of networks. Organisation Science 18(6), 1024-25.

Anand, G., Ward, P.T., Tatikonda, M.V. and Schilling, D.A. 2009. Dynamic capabilities through continuous improvement infrastructure. Journal of Operations Management 27(6), 444-461.

Apt, U.M. and Mason, R.O. 1995. Global Disaggregation of Information-intensive Services. Management Science 41(7), 1250-62.

Barney, J. B. 1999. How a firm's capabilities affect boundary decisions. Sloan Management Review 40, 137 145. 
Baxter, D., Gao, J., Case, K. Harding, J., Yong, B., Cochrane, S. and Dani, S. 2008. A framework to integrate design knowledge reuse and requirements management in engineering design. Robotics and Computer-Integrated Manufacturing 24(4), 585-593.

Birkinshaw, J. and Hagström, P. 2000. The flexible firm: Capability management in network organizations. Oxford University Press, New York.

Brock, D.M., Powell, M.J. and Hinnings, C.R. 2007. Archetypal Change and the Professional Service Firm, in W.A. Pasmore and R.W. Woodman (ed.) Research in organisational change and development, Volume 16, Emerald Group Publishing Limited, pp. 221-251.

Cetindamar, D., Phaal, R. and Probert, D. 2009. Understanding technology management as a dynamic capability: A framework for technology management activities. Technovation 29, 237-246.

Chase, R.B. and Apte, U.M. 2007. A history of research in service operations: What's the big idea? Journal of Operations Management 25, 375-386.

Chesbrough, H.W. 2003. Open innovation: The new imperative for creating and profiting from technology. Harvard Business School Press, Boston.

Choi, T.Y. and Hong, Y. 2002. Unveiling the structure of supply networks: Case studies in Honda, Acura and DaimlerChrysler. Journal of Operations Management 20(5), 469-493.

Christensen, C.M. and Sundahl, D. 2001. The process of building theory. Working paper No. 02-016. Harvard Business School, Boston, MA.

Coltman, T. and Devinney, T.M. 2013. Modeling the operational capabilities for customised and commoditized services. Journal of Operations Management 31, 555-566.

Droege, H., Hildebrand, D. and Forcada, M. 2009. Innovation in Services: present findings, and future pathways. Journal of Service Management 20(2), 131-155.

Dyer, J.H. and Noveoka, K. 2000. Creating and managing a high-performing knowledge-sharing network: the Toyota case. Strategic management Journal 21, 345-367.

Eisenhardt, K.M. 1989. Building theories from case study research. Academy of Management 14(1), 57-74.

Eisenhardt, K.M. and Martin, J.A. 2000. Dynamic capabilities: What are they? Strategic Management Journal 21, 1105-1121.

Eisenhardt, K.M. and Graebner, M.E. 2007. Theory building from cases: Opportunities and challenges. Academy of Management Journal 50(1), 25-32.

Ellram, L.M., Tate, W.L. and Billington, C. 2008. Offshore outsourcing of professional services: A transaction cost economies perspective. Journal of Operations Management 26, 148-163.

Fernandez-Stark, K., Bamber, P. and Gereffi, G. 2010. Engineering Services in the Americas, Centre on Globalisation, Governance and Competitiveness, Duck University, July, Durham NC, US.

Foss, N.J. 1999. Networks, capabilities, and competitive advantage. Scandinavian Journal of Management $15(1), 1-15$.

Freel, M. and de Jong, J.P.J. 2009. Market novelty, competence-seeking and innovation networking. Technovation 29, 873-884.

Goodale, J.C., Kuratko, D.F. and Hornsby, J.S. 2008. Influence factors for operational control and compensation in professional service firms. Journal of Operations Management 26, 669-688.

Grabher, G. and Powell, W.W. 2004. Networks: Critical studies in economic institutions. Edward Elgar Publishing Limited, UK.

Grant, R.M. 1991. The resource-based theory of competitive advantage: Implications for strategy formulation. California Management Review 33(3), 114-135.

Grant, R.M. 1996. Prospering in dynamically competitive environments: Organisational capabilities as knowledge integration. Organisation Science 7(4), 375-387.

Greenwood, R., Suddaby, R. and Hinings, C.R. 2002. Theorizing change: The role of professional associations in the transformation of institutionalized fields. Academy of Management Journal 45(1), 58-80. 
Håkansson, H., Ford, D., Gadde, L., Snehota, I. and Waluszewski, A. 2009. Business in networks. John Wiley and Sons, Glasgow.

Hansen, N., Zhang, Y. and Ahmed-Kristensen, S. 2013. Viewing engineering off-shoring in a network perspective: Addressing and managing risks, Journal of Manufacturing Technology Management 24(2), 154173.

Harvey, J. 1992. The operations management challenge in the delivery of complex professional services. International Journal of operations and production management 12(4), 100-7.

Harvey, J. 2011. Complex service delivery processes: Strategy to operations, 2nd Ed, ASQ Quality Press, Milwaukee, Wisconsin.

Harvey, J., Lefebvre, L.A. and Lefebvre, E. 1997. Flexibility and technology in services: A conceptual model. International Journal of Operations and Production Management 17(1), 29-45.

Hayes, R.H. and Wheelwright, S.C. 1984. Restoring our competitive edge: Competing through manufacturing. Wiley, New York.

Hayes, R.H., Pisano, G.P., Upton, D.M. and Wheelwright, S.C. 2005. Operations, strategy, and technology: Pursuing the competitive edge. Wiley, New Jersey.

Heineke, J. 1995. Strategic operations management decisions and professional performance in U.S. HMOs. Journal of Operations Management 13, 255-272.

Heineke, J. and Davis, M. 2007. The emergence of service operations management as an academic discipline. Journal of Operations Management 25(2), 364-374.

Helfat, C.E. and Peteraf, M.A. 2003. The dynamic resource-based view: Capability lifecycles. Strategic Management Journal 24, 997-1010.

HM Government. 2013. Growth is Our Business: A strategy for professional and business services. Department for Business, Innovation and Skills, Crown Copyright, London.

Hoegl, M. and Parboteeah, K.P. 2007. Creativity in innovative projects: How teamwork matters. Journal of Engineering and Technology Management 24(1-2), 148-166.

Hong, P., Vonderembse, M.A., Doll, W.J. and Nahm, A.Y. 2008. Role change of design engineers in product development. Journal of Operations Management 24(1), 63-79.

ISG. 2013. Robust growth for engineering services outsourcing: spend shifts to emerging markets, captives reassessed. Information Services Group, retrieved on 1st Feb 2014 via www.isg-one.com.

Javidan, M. 1998. Core competence: What does it mean in practice? Long Range Planning 31 (1), 60-71.

Karlsson, C. 2003. The development of industrial networks: challenges to operations management in an entraprise. International Journal of Operations and Production Management 23, 44-61.

Karlsson, C. and Skëld, M. 2007. The manufacturing entraprise: an emerging production network paradigm. Journal of Manufacturing Technology Management 18(8), 912-32.

Karpen, I.O., Bove, L.L. and Lukas, B.A. 2012, Linking Service-Dominant Logic and Strategic Business Practice: A Conceptual Model of a Service-Dominant Orientation. Journal of Service Research 15(1), 21-38.

Koka, B.R., Madhavan, R. and Prescott, J.E. 2006. The evolution of inter-firm networks: Environmental effects on patterns of network change. Academy of Management Review 31(3), 721-737.

Kotlarsky, J., Scarbrough, H, and Oshri, I. 2014. Coordinating expertise across knowledge boundaries in offshore outsourcing projects: the role of codification. MIS Quarterly 38(2), 607-627.

Krull, E., Smith, P. and Ge G. 2012. The internationalisation of engineering consulting from a strategy tripod perspective. The service industries journal 32(7), 1097-1119.

Kuemmerle, W. 1997. Building effective R\&D capabilities abroad. Harvard Business Review, March/April, 61-70.

Kusunoki, K., Nonaka, I. and Nagata, A. 1998. Organizational capabilities in product development of Japanese firms: A conceptual framework and empirical findings. Organisation Science 9(6), 699-718.

Lannes, W.J. 2001. What's engineering management? IEEE Transactions on Engineering Management 48(1), 107-110. 
Lewin, A. Y., Massini, S. and Peeters, C. 2009. Why are companies offshoring innovation? The emerging global race for talent. Journal of International Business Studies, 40(6), 901-925.

Lewis, M. and Brown, A. 2012. How different is Professional Service Operations Management? Journal of Operations Management 30(1-2), 1-11.

Lovelock, C. and Gummesson, E. 2004. Whither services marketing? In search of a paradigm and fresh perspectives. Journal of Services Research 7(1), 20-41.

Løwendahl, B. 2005. Strategic management of professional service firms. 3rd ed., Copenhagen Business School Press, Copenhagen.

Malhotra, N., Morris, T. and Hinings, C.R. 2006. Variations in organizational form among professional service organizations. In: Greenwood, R., Suddaby, R. (Eds.), Research in the Sociology of Organizations: Professional Service Firms, Vol. 26. Elsevier, Amsterdam, the Netherlands.

Malhotra, N. and Morris, T. 2009. Heterogeneity in professional service firms. Journal of Management Studies 46(6), 895-922.

Matos, L. and Afsarmanesh, H. 2004. Collaborative networked organizations: A research agenda for emerging business models. Springer, New York.

Majchrzak, A., Cooper, L.P. and Neece, O.E. 2004. Knowledge Reuse for Innovation. Management Science 50(2), 174-188.

Markus, M.L. 2001. Toward a theory of knowledge reuse: types of knowledge reuse situations and factors in reuse success. Journal of management information systems 18(1), 57-93.

Meredith, J. 1998. Building operations management theory through case and field research. Journal of Operations Management 16, 441-454.

Mills, J. and Platts, K. 2003. Competence and resource architectures. International Journal of Operations and Production Management 23(9), 977-994.

Moore, K. and Birkinshaw, J. 1998. Managing knowledge in global service firms: Centres of excellence. Academy Management Executive 12(4), 81-92.

NAE 2004. Report of the engineering of 2020: Visions of engineering in the new century. National Academy of Engineering, the National Academies Press, Washington.

NAE 2008. The off-shoring of engineering: Facts, unknowns, and potential implications. National Academy of Engineering of the National Academies, the National Academies Press, Washington.

Narasimhan, R., Swink, M. and Kim, S.W. 2006. Disentangling leanness and agility: An empirical investigation. Journal of Operations Management 24(5), 440-457.

ONS. 2013. United Kingdom Balance of Payments- The Pink Book. Office for National Statistics, Crown Copyright, Cardiff.

Peng, D.X., Schroeder, R.G. and Shah, R. 2008. Linking routines to operations capabilities: A new perspective. Journal of Operations Management 26(6), 730-748.

Podolny, J. and Page, K. 1998. Network forms of organisations. Annual Review of Sociology 24, 57-76.

Powell, W.W. 1990. Neither market nor hierarchy: Network forms of organisation. Research in Organisational Behaviour 12, 295-336.

Powell, A., Piccoli, G. and Ives, B. 2004. Virtual teams: a review of current literature and directions for future research. ACM SIGMIS Database 35(1), 6-36.

Prahalad, C.K. and Hamel, G. 1990. The core competence of the corporation. Harvard Business Review, May-June, 79-91.

Quinn, J.B. 1999. Strategic outsourcing: Leveraging knowledge capabilities. Sloan Management Review 40(4), 9-21.

Radnor, H.A. 2002. Researching your own professional practice: Doing interpretive research. Oxford University Press, Oxford.

RAEng 2010. Philosophy of Engineering. The Royal Academy of Engineering, London. 
Roth, A.V. and Menor, L.J. 2003. Insights into service operations management: a research agenda. Production and Operations Management 12 (2), 145-164.

Shi, Y. and Gregory, M. 1998. International manufacturing networks: To develop global competitive capabilities. Journal of Operations Management 16, 195-214.

Shah, R. and Ward, P.T. 2003. Lean Manufacturing: Context, Practice Bundles, and Performance, Journal of Operations Management 21, 129-p149.

Siggelkow, N. 2007. Persuasion with case studies. Academy of Management Journal 50(1), 20-24.

Singh, J. 2008. Distributed R\&D, cross-regional knowledge integration and quality of innovation output. Research Policy 37(1), 77-96.

Slack, N. and Lewis, M.A. 2002. Operations strategy. Prentice-Hall, Upper Saddle River, New Jersey.

Snow, C.C., Miles, R.E. and Coleman, H.J. 1992. Managing 21st century network organisations. Organisational Dynamics 20(3), 5-20.

Stuart, I., McCutcheon, D., Handfield, R., McLachlin, R., and Samson, D. 2002. Effective case study research in operations management: a process perspective. Journal of Operations Management 20(5), 419443.

Teece, D. 1981. The market for know-how and the efficient international transfer of technology. The Annuals of the American Academy of Political and Social Science 458(1), 81-96.

Teece, D.J., Pisano, G. and Shuen, A. 1997. Dynamic capabilities and strategic management. Strategic Management Journal 18(7), 509-533.

Tiwana, A. and Bush, A.A. 2005. Continuance in expertise-sharing networks: A social perspective. IEEE Transactions on Engineering Management 52(1), 85-101.

Vereecke, A., Van Dierdonck, R. and De Meyer, A. 2006. A typology of plants in global manufacturing networks. Management Science 52(11), 1737-50.

Von Nordenflycht. 2010. What is professional service firm? Toward a theory and typology of knowledgeintensive firms. Academy of Management Review 35(1), 184-187.

Von Nordenflycht. 2011. Dialogue- Let's get testing: making progress on understanding professional service firms. Academy of Management Review 36(1), 155-174.

Voss, C., Tsikriktsis, N. and Frohlich, M. 2002. Case research in operations management, International Journal of Operations and Production Management 22, (2), 195 - 219.

Voss, C. 2005. Alternative paradigms for manufacturing strategy. International Journal of Operations and Production Management 25(12), 1211-22.

Wagner, S., Hoisl, K. and Thoma, G. 2014. Overcoming localisation of knowledge- the role of professional service firms. Strategic Management Journal 35, 1671-1688.

Winter, S.G. 2003. Understanding dynamic capabilities. Strategic Management Journal 24, 991-995.

Yin, R.K. 2009. Case study research: Design and methods. Sage Publications, London.

Youngdahl, W. and Ramaswamy, K. 2008. Offshoring knowledge and service work: a conceptual model and research agenda. Journal of operations management 26, 212-221.

Zander, I. 1999. How do you mean 'global'? An empirical investigation of innovation networks in the multinational corporation. Research Policy 28, 195-213.

Zardkoohi, A., Bierman, L. and Panina, D. 2011. Dialogue- Revisiting a proposed definition of professional firms. Academ of Management Review 36(1), 180-184.

Zhang, Y. and Gregory, M. 2011. Managing global network operations along the engineering value chain. International Journal of Operations and Production Management 31(7), 736-764.

Zhang, Y. and Gregory, M. 2013. Towards a strategic view of engineering operations, Proceedings of the Institution of Mechanical Engineers, Part B: Journal of Engineering Manufacture 227(6), 767-780.

Zhang, Y., Gregory, M. and Shi, Y. 2014. Managing global engineering networks part I: Theoretical foundations and the unique nature of engineering, Proceedings of the Institution of Mechanical Engineers, Part B: Journal of Engineering Manufacture 228(2), 163-171. 


\section{Appendix 1: An overview of interviews}

\begin{tabular}{|c|c|c|}
\hline Case & Interviewees & Interviewers \\
\hline \multirow[t]{2}{*}{ Case A } & $\begin{array}{l}\text { Group director (1) } \\
\text { Chief engineers (3) } \\
\text { Project CEO(1) }\end{array}$ & The authors \\
\hline & $\begin{array}{l}\text { Project managers (3) } \\
\text { Engineers/consultants (5) }\end{array}$ & One doctoral researcher and one of the authors \\
\hline \multirow[t]{2}{*}{ Case B } & $\begin{array}{l}\text { VP corporate strategy (1) } \\
\text { Head of operations development (1) } \\
\text { Head of global engineering supply (1) }\end{array}$ & The authors \\
\hline & $\begin{array}{l}\text { General managers }(2) \\
\text { Engineers/project managers (4) }\end{array}$ & One doctoral researcher and one of the authors \\
\hline \multirow[t]{2}{*}{ Case C } & $\begin{array}{l}\text { Group VP (1) } \\
\text { Head of global engineering (1) } \\
\text { Director of engineering capabilities (1) }\end{array}$ & The authors \\
\hline & $\begin{array}{l}\text { Project managers (3) } \\
\text { Engineers/consultants (5) }\end{array}$ & Two research fellows and one of the authors \\
\hline \multirow[t]{2}{*}{ Case D } & $\begin{array}{l}\text { Division president (1) } \\
\text { Area manager (1) } \\
\text { Global programme directors(2) }\end{array}$ & The authors \\
\hline & $\begin{array}{l}\text { Engineering centre managers (2) } \\
\text { Engineers/projects managers (3) }\end{array}$ & One doctoral researcher and one of the authors \\
\hline \multirow[t]{2}{*}{ Case E } & $\begin{array}{l}\text { VP global engineering (1) } \\
\text { Group technology officer (1) } \\
\text { Senior strategists (2) }\end{array}$ & The authors \\
\hline & $\begin{array}{l}\text { Heads of engineering (3) } \\
\text { Engineers/project managers (5) }\end{array}$ & Two research fellows and one of the authors \\
\hline \multirow[t]{2}{*}{ Case F } & $\begin{array}{l}\text { VP engineering \& technology (1) } \\
\text { Global engineering director }(1) \\
\text { Lead engineer }(1)\end{array}$ & The authors \\
\hline & $\begin{array}{l}\text { Engineers/project managers (5) } \\
\text { Programme managers (2) }\end{array}$ & One doctoral researcher and one of the authors \\
\hline Cases A-F & $\begin{array}{l}\text { Industrial experts who are familiar with the } \\
\text { case companies and the sectors (12) }\end{array}$ & The authors \\
\hline
\end{tabular}




\section{Appendix 2: Case study protocol outline}

\section{$\underline{\text { Section 1-Introduction }}$}

\section{Building Network Capabilities for Global Engineering Services}

Aim- This project aims to explore novel approaches to improving the effectiveness and efficiency of engineering services in the current business environments. Our exploration will begin with identifying the key challenges in deploying, developing and sustaining scarce engineering resources in areas such as organisations, skills and tools for example.

Background- Rapid changes in the structure and operations of global activities are leading to new challenges for engineering services. Following our earlier projects focusing on the design and operations of global engineering networks since 2004*, we are keen to revisit the findings to provide support of current challenges and opportunities, and to explore the trajectories of key capability areas influencing engineering services. Main themes include network resources, network coordination, and network learning.

Approach- We would like to interview a small number of key people who have an in-depth view of global engineering services. Key issues identified in the interviews will be mapped to reveal emerging trends and capture generic patterns of network capabilities for engineering services. The study will build upon established frameworks drawing together engineering, management and social sciences.

Outputs- It is expected that this project will help to identify key trends in global engineering services. The findings will be used to help companies consider their response to global trends and to prioritise programmes to enhance performance.

Contacts- For further information, please get in touch with [name of the lead author] on telephone xxx, email xxx.

*Note- Links to background studies and references

\section{Section 2. Statement of Confidentiality}

All your responses are anonymous and all information that might in any way permit identification of you or your company will be regarded as strictly confidential. It will be used for the purposes of this research only, and will not be disclosed or released for any other purpose without your prior consent. You can withdraw your participation at any point of time during this project.

\section{Section 3. Generic Questions about Engineering Service Networks}

1) What's your position in your company, and how long have you been in this position?

2) Number of employees of your company:

Number of employees with engineering qualifications:

3) Number of subsidiaries/facilities of your company and their locations:

Number of subsidiaries/facilities with engineering functions and their locations:

4) Revenues of your company in the previous financial year (in million $\mathfrak{f}$ ):

5) What are the main engineering services/business areas of your company?

6) What's the market position of your company in global competition?

7) What is the main strategic objective(s) of your engineering service operations?

8) Your contacts:

Email: Telephone:

Address: 


\section{Section 4. Network Capabilities}

\subsection{Network Resources}

Accessing, mobilising and restructuring dispersed engineering resources

- What are the network resources contributing to your global service operations?

- How do you manage these resources for effective value creation in global service operations?

\subsection{Network Coordination}

Coordinating and integrating engineering operations on a global scale

- Do you have established processes to coordinate your global service operations? If so, please describe the most important ones.

- How have these coordination processes contributed to effective value creation in your global service operations?

\subsection{Network Learning}

Capturing, creating and disseminating internal and external engineering knowledge

- What are the key learning mechanisms for your global service operations?

- How have these learning mechanisms contributed to effective value creation in your global service operations? 